\title{
Evidence of Population Declines among Common Eiders Breeding in the Belcher Islands, Northwest Territories
}

\author{
GREGORY J. ROBERTSON ${ }^{1}$ and H. GRANT GILCHRIST ${ }^{2}$
}

(Received 26 January 1998; accepted in revised form 27 May 1998)

\begin{abstract}
Information regarding the status of common eiders Somateria mollissima breeding in the Canadian Arctic is sorely lacking. In 1997, we surveyed five island archipelagoes in the Belcher Islands in Hudson Bay $\left(56^{\circ} 00^{\prime}-57^{\circ} 30^{\prime} \mathrm{N}, 79^{\circ} 30^{\prime}-80^{\circ} 00^{\prime} \mathrm{W}\right)$ from 3 to 23 July. Our results were compared with eider surveys of the same islands completed between 1985 and 1989 using a standard protocol. We found 1416 eiders on 431 islands. Most (94.1\%) were found while the female was still incubating. In all five island groups surveyed, the number of nesting eiders declined significantly (overall decline of 75.0\% from 1985-88 to 1997, range: $62.3-84.0 \%$ ). In 1997, nesting islands and adjacent waters were free of ice, and eiders nested early and laid large clutches (range: $4.0-4.4 \pm 1.0-1.2 \mathrm{SD}$ ). These conditions indicate a good nesting season, and we inferred that extensive nonbreeding by female eiders in 1997 did not account for the observed decline. A large reported die-off of eiders during the winter of 1991-92, which occurred when areas of open water froze, was the most likely cause of the decline. Our results raise serious conservation concerns, because eider populations are sensitive to reductions in adult survival and this population is harvested throughout the year by subsistence hunters.
\end{abstract}

Key words: common eider, Somateria mollissima sedentaria, Belcher Islands, population decline, Hudson Bay

RÉSUMÉ. On a grandement besoin d'information sur le statut de l'eider à duvet Somateria mollissima qui niche dans l'Arctique canadien. En 1997, du 3 au 23 juillet, on a effectué des relevés dans cinq archipels des îles Belcher situées dans la baie d'Hudson $\left(56^{\circ} 00^{\prime}-57^{\circ} 30^{\prime} \mathrm{N}\right.$., $79^{\circ} 30^{\prime}-80^{\circ} 00^{\prime} \mathrm{O}$.) On a comparé nos résultats suivant un protocole normalisé à des relevés d'eiders effectués dans les mêmes îles entre 1985 et 1989 . On a trouvé 1416 eiders dans 431 îles. La plupart (94,1 p. cent) ont été relevés alors que la femelle était encore en train de couver. Dans chacun des cinq groupes d'îles étudiés, le nombre d'eiders nicheurs avait enregistré une baisse importante (déclin global de 75,0 p. cent de 1985 à 1988, fourchette de 62,3 à 84,0 p. cent). En 1997, les îles de nidification et les eaux adjacentes étaient libres de glace; les eiders ont niché tôt et la taille des pontes était importante (fourchette: 4,0 à 4,4 \pm écart-type de 1,0 à 1,2). Ces conditions sont révélatrices d'une bonne saison de reproduction, et nous en déduisons que la non-reproduction généralisée par les eiders femelles en 1997 n'explique pas le déclin enregistré. C'est très probablement la mortalité massive d'eiders enregistrée au cours de l'hiver de 1991-92, survenue quand les surfaces d'eau libre ont gelé, qui a été responsable du déclin. Nos résultats soulèvent d'importantes questions en matière de conservation, car les populations d'eiders sont sensibles aux baisses de survie adulte et que, tout au long de l'année, cette population fait l'objet de prélèvements dans le cadre de la chasse de subsistance.

Mots clés: eider à duvet, Somateria mollissima sedentaria, îles Belcher, déclin de population, baie d'Hudson

Traduit pour la revue Arctic par Nésida Loyer.

\section{INTRODUCTION}

There is serious concern about the status of many sea duck populations (Kertell, 1991; Stehn et al., 1993). Sea duck populations are vulnerable to decline because they are typically long-lived and have delayed reproductive maturity and low rates of reproduction (Palmer, 1976). Consequently, even minor reductions in the survival of adults can send populations into decline (Abraham and Finney,
1986; Goudie et al., 1994), and populations are slow to recover once conditions improve (Prestrud and Mehlum, 1991).

Little is known about the annual productivity, population size, or population trends of many sea duck populations (Goudie et al., 1994). This is especially true for populations breeding in northern regions because of the logistics and financial costs associated with studying sea duck populations in the North. Existing information about

\footnotetext{
${ }^{1}$ Atlantic Cooperative Wildlife Ecology Research Network, P.O. Box 45111, University of New Brunswick, Fredericton, New Brunswick E3B 6E1, Canada; present address: Canadian Wildlife Service, 6 Bruce Street, Mount Pearl, Newfoundland A1N 4T3, Canada; greg.robertson@ec.gc.ca

${ }^{2}$ Canadian Wildlife Service, Environment Canada, Suite 301, 5204 50th Avenue, Yellowknife, Northwest Territories X1A 2R2, Canada; grant.gilchrist@ec.gc.ca

(C) The Arctic Institute of North America
} 
common eiders Somateria mollissima breeding in the Canadian Arctic is either insufficient or too out of date to be useful in effectively managing these eider populations (Reed and Erskine, 1986; Circumpolar Seabird Working Group, 1997; Dickson, 1997).

The Hudson Bay eider Somateria mollissima sedentaria is a subspecies of the common eider. It breeds on the east and west coasts of Hudson and James Bays and on the Belcher, Sleeper, and Ottawa Islands (Snyder, 1941). Small numbers may also breed on Southampton, Coats, and Mansel Islands in northern Hudson Bay. The entire population of the sedentaria subspecies winters exclusively in Hudson Bay, restricted to polynyas and floe edges near the Belcher Islands, off the west coast of Quebec, and perhaps in Roes Welcome Sound (Abraham and Finney, 1986). This is one of the only waterfowl species in the world that spends the entire year in Arctic waters (Freeman, 1970). Very little is known about this population, including its population trends and sources of natural and humaninduced mortality.

Recent reports by local hunters in the Belcher Islands suggest that eider numbers have declined (McDonald et al., 1997), but quantitative information is lacking. Eiders are very important to the residents of Sanikiluaq: they are hunted for food, their eggs are collected in the summer, and their down (and, traditionally, their skins) are used to make clothing (Reed, 1986; Nakashima, 1991). Since the status of the common eiders breeding in the Belcher Islands is uncertain, we initiated a study to address concerns for this population. In this study, we compare 1997 counts of active eider nests with data collected on the same islands, using a standard protocol, between 1985 and 1988.

\section{METHODS}

\section{Study Area}

The Belcher Islands are located in southeastern Hudson Bay $\left(56^{\circ} 00^{\prime}-57^{\circ} 30^{\prime} \mathrm{N}, 79^{\circ} 30^{\prime}-80^{\circ} 00^{\prime} \mathrm{W}\right)$ (Fig. 1). The community of Sanikiluaq (650 residents) is located on Flaherty Island on the northern tip of the archipelago. Many of the male residents are subsistence hunters who travel widely throughout the region, by boat in July and August and by snowmobile in winter (Nakashima, 1991; Wein et al., 1996). Small islands in the Belcher Island group support breeding Hudson Bay eiders. Arctic foxes Alopex lagopus also occur in the Belcher Islands but are rarely present on small islands further than $1 \mathrm{~km}$ from the large islands once the sea ice is gone (Manning, 1976; Nakashima and Murray, 1988). Nesting eiders are generally found only on these small offshore islands, although some nest on islands in large inland lakes (Freeman, 1970; Manning, 1976). Nesting islands are typically low-lying, rocky, and sparsely vegetated with short grasses and sedges, small perennials, moss, and prostrate willow species Salix spp.; they range in area from approximately 0.01 to $500 \mathrm{ha}$.

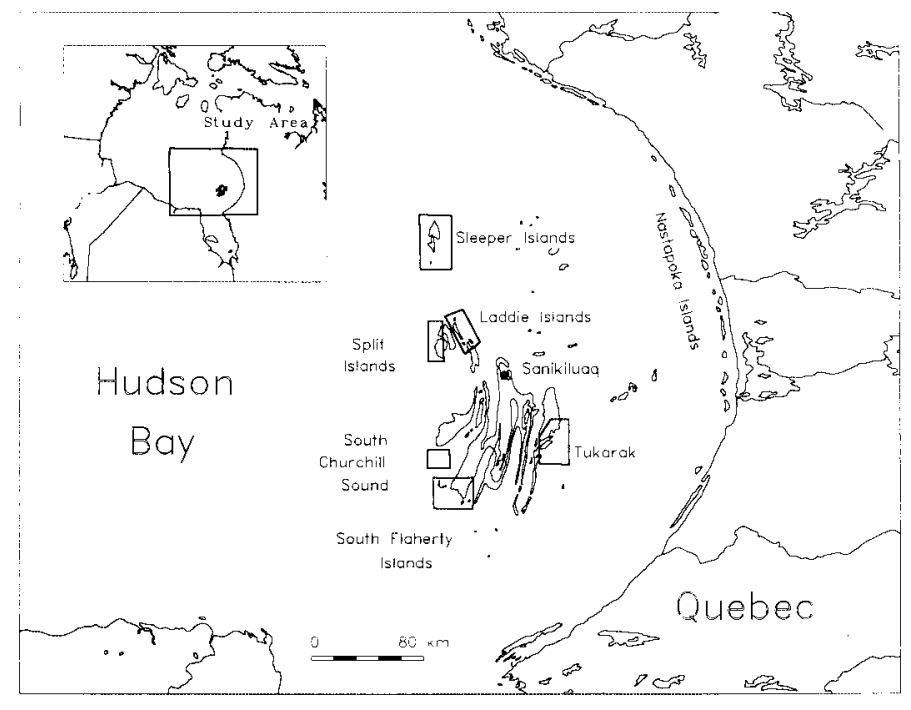

FIG 1. Location of study area in the Belcher Islands, Hudson Bay, Northwest Territories. Rectangles show the six study areas surveyed in the 1980s. All but Tukarak were resurveyed in 1997.

Herring gulls Larus argentatus, glaucous gulls $L$. hyperboreus, black guillemots Cepphus grylle, and arctic terns Sterna paradisaea commonly nest on islands with eiders; the first two species are significant predators of eider eggs and ducklings (Munro and Bédard, 1977; Swennen, 1989; Mehlum, 1991a).

\section{Survey Regions}

Six island groups (hereafter termed regions) within the Belcher Islands were delineated and surveyed in the 1980s (Fig. 1): 1) South Flaherty Islands, surveyed in 1986 (Fleming and McDonald, 1987); 2) South Churchill Sound, surveyed in 1988 (McDonald and Fleming, 1990); 3) Laddie Islands, surveyed in 1985 (Nakashima and Murray, 1988); 4) Split Islands, surveyed in 1985 (Nakashima and Murray, 1988); 5) Sleeper Islands, surveyed in 1985 (Nakashima and Murray, 1988); and 6) East Tukarak Islands, surveyed in 1989 (McDonald and Fleming, 1990). In 1997, the South Flaherty and South Churchill Sound Islands were surveyed first, between 3 and 8 July. We then surveyed the Sleeper Islands, between 10 and 13 July, and finally the Split and Laddie Islands, between 20 and 23 July (Fig. 1). We did not have time to survey East Tukarak before the end of the eider incubation period.

\section{Survey Methods}

We used the same survey method, developed by Chapdelaine et al. (1986), that was used by previous field crews, to ensure that our data were comparable to the results of previous surveys. In the original survey design, all islands in selected survey regions were numbered on 1:50 000 topographic maps. Only islands less then 500 ha in size were considered suitable eider nesting habitat; larger islands usually harboured arctic foxes and did not 
support nesting eiders. Fifty percent of islands were randomly chosen and subsequently surveyed by the original crews. In 1997, we attempted to revisit the random sample of islands. Our survey crew consisted of between 11 and 13 residents of Sanikiluaq and the senior author. We traveled between regions in a large fishing vessel and reached islands using either a freighter canoe or an aluminum boat.

Selected islands were surveyed by one of two methods. If the island was small $(<0.05 \mathrm{ha})$ and could be completely examined from the sea, we surveyed it visually from a boat; if there was evidence of eiders nesting on the island, we landed and examined the island on foot. For islands surveyed on foot, the entire island was examined by crews of 3 to 6 field workers, who walked $10 \mathrm{~m}$ apart from each other across each island. If an island was not covered in one sweep, the crew member at the outside of the line marked the extent of the first pass with rocks or sticks. The crew then turned around and walked back, counting only nests on the opposite side of the previously marked line. In this manner, islands were completely surveyed with little risk of missing nests or counting nests twice. Nests were easily located because there was little vegetation.

When a nest was found, its contents were reported to one crew member who recorded the information. For each nest, we recorded the species, the number of eggs, and the status of the nest: incubating, in the process of hatching, all eggs hatched, or destroyed/depredated. Nests were assumed to be incubated by females if there was down in the nest and the eggs were warm to the touch. No clutches where the female was still laying (i.e., one to three eggs in a nest cup covered with nest material) were found.

\section{Data Analysis}

We were not able to return to all islands surveyed by the original crew in the South Flaherty region (about 30 islands, $16 \%$ of original survey) and the Sleeper Islands region (about 50 islands, $32 \%$ of original survey) because of logistical constraints. Most of the islands (about 35) we missed in the Sleeper Island region were part of a complex of islands lying between the large north and south main islands. Nakashima and Murray (1988) did not find any nests on these islands and considered them unsuitable eider nesting habitat because they were too close to the large islands; therefore, we actually only missed about 15 suitable nesting islands (or 10\%). To reduce the biases in comparing between the two surveys, only islands that were surveyed both in the 1980s and in 1997 were compared.

Islands with no nesting eiders in both years were removed from the data set prior to the comparative analysis. Typically, these islands either were too close to the mainland and presumably accessible to foxes or were small shoals prone to flooding at high tide. Because the distribution of nests per island was not normal, data were log transformed after adding one nest to each island; this transformation effectively homogenized the variance between the two samples. A paired t-test was used on these transformed data to detect a change in the numbers of nesting eiders between the two survey periods on each island. A critical $\alpha=0.05$ was used throughout. In addition, because the time that had elapsed between surveys varied from 9 to 12 years, an annual population growth rate (Caswell, 1989) was calculated for each region:

$$
\lambda=e^{\frac{\ln (N(T) / N(O))}{T}}
$$

where lambda is the annual population growth rate, $\ln$ is the natural logarithm, $e$ is the base of the natural logarithm, $N(T)$ is the population size at $T$ years after the first survey and $N(0)$ is the population size during the first survey. Although population growth rates present a constant rate of population size change, we do not imply that any changes in population size have occurred at a constant rate.

\section{RESULTS}

\section{Survey}

Summary statistics for the common eider nest survey are presented in Table 1. The number of islands surveyed within each region ranged from 27 to 153 islands, and the number of nests found within each region ranged between 110 and 468 nests. Over half of the islands in any given region did not have eiders nesting on them. The mean number of nests on each island was lowest in the Laddie, Split, and South Flaherty regions (1.6-2.8 nests/island). More nests were found on islands in the Sleeper and South Churchill Sound regions (4.4 and 10.5 nests/island, respectively). The Sleeper and Churchill Sound regions had single islands with comparatively large numbers of nests on them (over 100), increasing the mean and the variance in the number of nests found per island. Nesting eiders were most evenly distributed across islands on the South Flaherty Islands (52 of 153 islands, $34.0 \%$ ) and were most restricted on the Split Islands (9 of 62 islands, 14.5\%).

Most active nests $(94.1 \%)$ were found during incubation (Table 1). The first hatching nest was found on 12 July in the Sleeper Islands; this was the only hatching nest found in the Sleeper Island region. The rest of the hatching or hatched nests were found in the Laddie Islands and Split Islands, the regions surveyed later in the season $(20-23$ July). Mean clutch size of incubated clutches was $4.4 \pm$ 1.0-1.2 eggs/nest in South Flaherty, South Churchill Sound, and the Sleeper Islands, while in the Split and Laddie Islands, clutch size averaged $4.0 \pm 1.1-1.2$ eggs/nest.

\section{Comparisons Between the 1980s and 1997}

The eider population nesting in the Belcher Islands has declined dramatically since the 1980 s (Table 2 ). The nests counted in 1997 numbered $62 \%$ to $84 \%$ less than those counted between 1985 and 1988. The number of nesting 
TABLE 1. Summary statistics for common eiders nesting in the Belcher Islands, 1997.

\begin{tabular}{|c|c|c|c|c|c|c|}
\hline & $\begin{array}{l}\text { South Flaherty } \\
\text { Islands }\end{array}$ & $\begin{array}{l}\text { South Churchill } \\
\text { Sound }\end{array}$ & Sleeper Islands & Split Islands & Laddie Islands & Total \\
\hline Dates of surveys & 3-6 July & 7-8 July & 10-13 July & 20 July & 22-23 July & 3-23 July \\
\hline No. of islands surveyed & 153 & 27 & 107 & 62 & 82 & 431 \\
\hline No. of eider nests & 422 & 283 & 468 & 110 & 133 & 1416 \\
\hline No. of nests per island (range) & $2.8 \pm 7.6(0-55)$ & $10.5 \pm 31.0(0-149)$ & $4.4 \pm 17.6(0-146)$ & $1.8 \pm 6.4(0-37)$ & $1.6 \pm 4.9(0-39)$ & $3.3 \pm 13.0(0-149)$ \\
\hline No. of islands with nests & $52(34.0 \%)$ & $7(25.9 \%)$ & $24(22.4 \%)$ & $9(14.5 \%)$ & $24(29.3 \%)$ & $116(26.9 \%)$ \\
\hline \multicolumn{7}{|l|}{ Percent of nests in status: } \\
\hline - 1 (Incubating) & 99.3 & 97.2 & 92.3 & 80.9 & 88.0 & 94.1 \\
\hline-2 (Hatching) & 0 & 0 & 0.2 & 13.7 & 2.2 & 1.3 \\
\hline-3 (Hatched) & 0 & 0 & 0 & 2.7 & 4.5 & 0.6 \\
\hline-4 (Destroyed) & 0.3 & 2.8 & 7.5 & 2.7 & 5.3 & 4.0 \\
\hline Mean clutch $\operatorname{size}^{1}$ (sample size) & $4.43 \pm 1.03(419)$ & $4.40 \pm 1.24(275)$ & $4.38 \pm 1.12(432)$ & $3.96 \pm 1.19(89)$ & $4.02 \pm 1.06(117)$ & $4.34 \pm 1.13(1332)$ \\
\hline
\end{tabular}

${ }^{1}$ Only incubating nests were used for calculation of clutch size.

eiders declined in all regions surveyed. The most precipitous declines occurred in the northern island chains, the Laddie, Split, and the Sleeper Islands (79\%-84\%). The South Flaherty and South Churchill Sound Islands experienced a lower, yet substantial, decline $(62 \%-69 \%)$. The population growth rates also suggest a decline (Table 2) that was fastest in the northern regions (growth rates of $0.858-0.879$ ); by comparison, the South Flaherty and South Churchill Sound Islands had growth rates of 0.879 to 0.915 .

The number of eiders nesting on individual islands within each region also declined significantly (Table 2). Of the 160 islands that had eiders nesting on them in either the 1980 s or 1997, only 44 of them gained (34 islands, or $21.3 \%$ ) or maintained (10 islands, or $6.3 \%$ ) the same number of nests in 1997. On those islands where the number of nests increased, the gains were slight ( mean $=5$ nests; range $=1$ to 22 ) compared to the losses on other islands $($ mean $=38$; range $=$ 1 to 383 nests). The mean clutch size in 1997 was similar to (Sleeper, Split, and Laddie Islands) or slightly higher than (South Flaherty Island, South Churchill Sound) clutch size in the 1980s (Table 3).

\section{DISCUSSION}

\section{Survey}

Eider nests were not evenly distributed among the islands we surveyed, as many islands did not have eiders nesting on them. Islands without eiders nesting on them were usually 1) small, shallow and devoid of vegetation, 2) close to the mainland and in many cases joined to the mainland at low tide, or 3 ) very large (> $100 \mathrm{ha}$ ) (Fleming and McDonald, 1987; Nakashima and Murray, 1988; McDonald and Fleming, 1990). Eiders may perceive these larger islands as a mainland and not nest on them to avoid arctic foxes. Alternatively, they may have experienced poor breeding success on these islands and therefore moved to other islands. In fact, on one of these larger islands, we did see an arctic fox and found eight depredated nests. Foxes may be able to swim to these islands to gain access to the eider nests or they may choose to settle on these islands before the ice melts and strands them there.

Only the Sleeper and South Churchill Sound regions had islands that supported reasonably large colonies of eiders (> 100 birds). The Sleeper Islands and South Churchill Sound regions were the two areas most isolated from the community of Sanikiluaq. Furthermore, islands that supported large colonies within those regions tended to be at the periphery of the archipelago and isolated from large islands. Nakashima and Murray (1988) and McDonald and Fleming (1990) provide a detailed description of islands that support large colonies.

Since eider clutches began hatching in the third week in July, egg laying was probably initiated sometime from mid- to late June, assuming a 24-25 day incubation period (Erikstad and Tveraa, 1995) and an approximately 24 hour egg-laying period (Watson et al., 1993). This schedule was similar to the timing of egg laying observed by Nakashima and Murray (1988) in 1985, a relatively good year for breeding eiders. Interestingly, nesting occurred later than in populations on the west side of Hudson Bay, where egg laying began in the last week of May (Robertson, 1995). Eiders nesting in the Belcher Islands had a nesting chronology similar to that of common eiders Somateria $\mathrm{m}$. borealis nesting over $1000 \mathrm{~km}$ to the north (Cooch, 1965; Prach et al., 1986): this similarity indicates the severity of conditions in the Belcher Islands, despite their southerly latitude.

In the Split Island and Laddie Island regions, clutch sizes were lower (4.0 eggs) than in the other regions (4.4 eggs). The lower clutch sizes found in the Split and Laddie Islands are probably an artifact of the timing of our surveys, because these areas were surveyed last (20-23 July), and clutches with the largest number of eggs had probably already hatched. Eiders show a seasonal decline in clutch size, so larger clutches typically hatch first (Milne, 1974; Spurr and Milne, 1976; Mehlum, 1991a; Robertson, 1995) and hatched clutches were not included in our calculation of clutch size. Partial egg predation may also have lowered clutch sizes in the regions surveyed last, as predators would have had longer to search for and consume the eggs. 
TABLE 2. Comparison of survey results for mid-1980s and 1997 and tests (paired t-test, one-tailed) of whether the eider nesting population has declined from the 1980s to 1997 for each individual island.

\begin{tabular}{|c|c|c|c|c|c|c|c|c|}
\hline & Number of islands ${ }^{1}$ & Number of nests -1980 s & Number of nests -1997 & $\%$ decline & $\lambda^{2}$ & $\mathrm{n}^{3}$ & $t^{4}$ & $p^{5}$ \\
\hline South Flaherty Islands & 150 & 1113 & 420 & $62.3 \%$ & 0.915 & 63 & 2.81 & 0.0033 \\
\hline South Churchill Sound & 27 & 899 & 283 & $68.5 \%$ & 0.879 & 9 & 3.34 & 0.0052 \\
\hline Sleeper Islands & 108 & 2204 & 468 & $78.7 \%$ & 0.879 & 36 & 4.55 & 0.0001 \\
\hline Split Islands & 61 & 602 & 110 & $81.7 \%$ & 0.868 & 14 & 2.01 & 0.0329 \\
\hline Laddie Islands & 80 & 833 & 133 & $84.0 \%$ & 0.858 & 38 & 6.32 & 0.0001 \\
\hline Total & 426 & 5651 & 1414 & $75.0 \%$ & - & 160 & 7.87 & 0.0001 \\
\hline
\end{tabular}

${ }^{1}$ Number of islands surveyed in both 1980s and 1997

${ }^{2}$ Annual population growth rate

${ }^{3}$ Only islands having nests on them in at least 1 of the 2 surveys were used

${ }^{4}$ Paired t-test, statistic based on log-transformed data

${ }^{5}$ One-tailed test

TABLE 3. Comparison of common eider clutch sizes in 1980s and 1997 in the Belcher Islands. Only incubated clutches were included in the sample.

\begin{tabular}{|c|c|c|c|c|}
\hline & \multicolumn{2}{|c|}{ Clutch size } & \multirow[b]{2}{*}{$t$} & \multirow[b]{2}{*}{$p$} \\
\hline & $1980 \mathrm{~s}$ & 1997 & & \\
\hline South Flaherty Islands & $4.04 \pm 1.05(1980)$ & $4.43 \pm 1.03(419)$ & 7.35 & 0.0001 \\
\hline South Churchill Sound & $4.09 \pm 1.90(876)$ & $4.40 \pm 1.24(275)$ & 2.86 & 0.002 \\
\hline Sleeper Islands & $4.28 \pm 1.38(2577)$ & $4.38 \pm 1.12(432)$ & 1.53 & 0.063 \\
\hline Split Islands & $3.92 \pm 1.42(491)$ & $3.96 \pm 1.19$ & 0.27 & 0.395 \\
\hline Laddie Islands & $4.00 \pm 1.18(649)$ & $4.02 \pm 1.06(117)$ & 0.18 & 0.427 \\
\hline Total & $4.13 \pm 1.37(6376)$ & $4.34 \pm 1.12(1332)$ & 5.73 & 0.0001 \\
\hline
\end{tabular}

\section{Interpretation of Survey Results}

Our surveys indicate that the number of eiders nesting in the Belcher Islands has declined by $75 \%$ since $1986-$ 88. One possible interpretation is that adult females have dispersed from the Belcher Islands archipelago to breed in other areas. This kind of large-scale dispersal is unlikely, because the nearest suitable habitat occurs in the Nastapoka Islands, approximately $160 \mathrm{~km}$ east of the Belcher Islands. A mass movement of breeding eiders over such a distance has never been documented. Indeed, eiders are highly philopatric to nesting areas (i.e., island groups), even following years of successive reproductive failure (Cooch, 1965; Reed, 1975; Swennen, 1976, 1990).

Another possible explanation for the observed decline is that our surveys failed to detect many of the female eiders nesting in the Belcher Islands in 1997. This could occur if there had been small-scale dispersal of adult females away from the islands surveyed. A few adult females will move to nearby nesting islands for subsequent breeding attempts (Wakeley and Mendall, 1986). Survey results may be wrongly interpreted as population declines if eiders disperse from large colonies and establish small colonies that are difficult to find (Boertman et al., 1996; D. Boertman, pers. comm. 1997). Dispersal of nesting eiders may be expected from large colonies that experience persistent human disturbance. Boertman et al. (1996) concluded that their survey coverage, which was restricted to several large islands, was insufficient to rule out such dispersal.
Our surveys covered up to $50 \%$ of randomly selected islands in five study regions. Thus, it is unlikely that we missed a sufficient number of islands with high nesting densities to account for the decline. Further, we found that 1) eider nesting densities declined in all regions irrespective of the size of the island or of the original colony; 2) there was no obvious shift in eider distribution within or between regions; and 3 ) few islands $(<22 \%)$ had more nests on them in 1997 than in 1986-88.

Extensive nonbreeding, a reduction in the absolute number of breeding females eiders, or both may explain the observed decline in the number of nesting eiders. Up to $65 \%$ of female eiders will not breed in years with poor conditions (Coulson, 1984). Poor years can often be detected by surveys because 1 ) the clutch size of females that do breed is often significantly lower (by up to one egg, Coulson, 1984; Mehlum, 1991b; Robertson, 1995); 2) the date of laying is often delayed (Mehlum, 1991b; Robertson, 1995); and 3) nesting densities are reduced at the regional level although on any given island the densities may be very high (Mehlum, 1991b; G.J. Robertson, unpubl. data).

In 1997, weather conditions favoured a good nesting season for eiders in the Belcher Islands. Nesting islands and adjacent waters were free of ice early in June, eiders laid large clutches, and they nested relatively early. Indeed, in two of the five regions, clutch sizes were actually larger in 1997 than in the late 1980s, and in the other three there was no significant difference. Clutch sizes of 4.0-4.4 eggs are normal for common eiders (Swennen, 1983; 
Hario and Selin, 1988) and similar to those of Hudson Bay eiders nesting near Churchill during good breeding seasons (Robertson, 1995). It appears that 1997 was a good breeding year for eiders in the Belcher Islands, and we infer that the reduction in the number of nesting females is due to a real numerical decline in the population rather than to extensive nonbreeding by females.

\section{Reasons for Eider Population Decline}

Harvest: Common eiders are harvested extensively around the Northern Hemisphere by subsistence and sport hunters (Reed and Erskine, 1986). Several northern populations are harvested throughout the year, and it is unknown whether these levels of harvest are sustainable. The declines of several populations have been attributed to overharvesting. In Svalbard, the breeding eider population declined dramatically in the late 1800 s and early 1900 s because of extensive egging and down collection (Rossnes, 1991). Sanctuaries were established in 1963, and since then the population has remained stable (Mehlum, 1991b). However, this population has not recovered to numbers present at the turn of the century (Prestrud and Mehlum, 1991). In the western Canadian Arctic, the numbers of common and king eiders Somateria spectabilis migrating past Point Barrow have declined from approximately 1000000 eiders counted in the 1950s and 1960s to about 500000 counted in 1994, and harvest may have been a contributing factor (Suydam et al., 1997). However, Fabijan et al. (1997) concluded that harvest in this region was well within sustainable levels. Cooch (1986) documented a $67 \%$ reduction over 20 years in the number of eiders nesting in the West Foxe Islands near Cape Dorset, which was apparently due to hunting and egging by the local community.

Hudson Bay eiders are harvested for their meat, and their down and eggs are collected during the summer in the Belcher Islands (Nakashima, 1991). The community of Sanikiluaq has an eiderdown industry: down comforters and garments are produced within the community and sold in Canada and Europe (McDonald and Fleming, 1990). It is unlikely that disturbance at colonies caused by down collection resulted in recent population declines, because commercial down collection ceased in the region during the 1990s because of weak market demand. Additionally, studies have shown that responsible down harvesting does not necessarily have a negative impact on eider productivity (Mehlum et al., 1991), although down collection may increase egg predation and nest abandonment (Reed, 1986).

The hunting of adult common eiders occurs throughout the year in the Belcher Islands but is concentrated in fall and winter (Reed and Erskine, 1986). The annual harvest was estimated to be approximately 6000 birds in the early 1980s (Reed and Erskine, 1986). In addition to taking birds, hunting also disturbs birds, which may impair body condition and reduce nesting success (Korschgen, 1977). Population estimates of the Hudson Bay eider are crude and now out of date (Abraham and Finney, 1986; Nakashima and Murray, 1988). Consequently, it is not possible to evaluate whether current levels of harvest are sustainable or whether harvest has contributed to the observed population declines.

Winterkill: Local residents in Sanikiluaq reported population declines of common eiders prior to this study (McDonald et al., 1997), and our findings support their observations. Residents of Sanikiluaq are very knowledgeable about the ecology and status of eider populations in the Belcher Islands (Nakashima, 1991). Residents attribute the declines to a mass die-off of eiders that they observed during the winter of 1991-92, when eiders were concentrated in polynyas and open water at the floe edges that froze over. Recurring polynyas and open water floe edges are extremely important ecologically. Marine wildlife often rely on these locations as wintering areas at a time of year when populations are severely constrained geographically and energetically (Stirling and Cleator, 1981; Stirling, 1997).

Small recurring polynyas form among the Belcher Islands in southern Hudson Bay because strong currents prevent the formation of ice. Shifting pack ice also provides temporary areas of open water around the Belcher Islands. The polynyas and open-water leads in the Belcher Islands and western Quebec are the only permanent areas of open water in southeastern Hudson Bay during winter (Smith and Rigby, 1981). Marine mammals and birds that winter in the region (e.g., walrus, seals, and common eiders; McDonald et al., 1997; Stirling, 1997) are restricted to these areas, and they are apparently vulnerable to die-offs because they cannot escape to alternative habitats if polynyas and open-water leads freeze.

The status of polynyas and the shifting ice pack in the Belcher Islands is uncertain. Since the late 1980s, longterm residents of the Belcher Islands have witnessed dramatic changes in regional ice conditions (McDonald et al., 1997). Areas that have been historically free of ice are reported to freeze during some winter months, and areas of shifting pack ice between mainland Quebec and the Belcher Islands also freeze solid. Changes in the timing of freshwater run-off from Quebec and global weather changes have been suggested as possible causes of this change (McDonald et al., 1997). It is unknown whether these events are increasing in frequency, and what impact they have on resident wildlife such as wintering eider populations.

The frequency and magnitude of die-offs in winter and the long-term impact that they have on the Hudson Bay eider population are unknown. Clearly, the relationship between polynyas and open-water leads and the mortality of eiders is an important component of eider population dynamics in Hudson Bay. Our results suggest that access to suitable wintering habitat is critical for eiders and that wintering habitat limitation or degradation may be playing a role in the decline of other eider species (Kertell, 1991; Stehn et al., 1993). Future research should focus on both 
the physical characteristics of the ocean that maintain open water in the Belcher Islands during winter (e.g., mapping their location, monitoring the timing of their occurrence), as well as quantifying habitat use, diet, and foraging ecology of the eiders surviving within the polynyas and at the floe edge. The potential for continued subsistence harvest in Hudson Bay to slow or prevent the recovery of eider populations following a natural catastrophe, such as a winterkill, also warrants consideration.

\section{ACKNOWLEDGEMENTS}

Lucassie Arragutainaq, Jr. and the Sanikiluaq Hunters and Trappers Association hired the survey crew and organized all of the provisions and logistics for the crew. D. Nakashima, D. Murray, and A. Reed organized the first survey, and without their effort this study would not have been possible. Miriam McDonald and Brian Fleming kindly let us use their survey data from the 1980s and were a valuable help in organizing this year's survey. Maureen Kay (CWS) arranged the logistics from Yellowknife, and Steven Pepper assisted with the figures. We thank Annie Arragutainaq, Caroline Arragutainaq, Johnassie Arragutainaq, Lucassie Inuktaluk, Meena Ippak, Mina Inuktaluk, Joseph Kigilak, Noah Meeko, Moses Mickiyuk, Sarah Mickiyuk, and Alec Sala for assistance with the field work. We especially thank Paulossie Mickiyuk, who captained the Pitsiulak, and Johnassie Inuktaluk, who led the field crews. Finally, we thank Lynne Dickson and Tony Diamond, who provided helpful comments on earlier drafts of the manuscript. This research was funded by the Nunavut Wildlife Research Trust and the Canadian Wildlife Service of Environment Canada.

\section{REFERENCES}

ABRAHAM, K.F., and FINNEY, G.H. 1986. Eiders of the eastern Canadian Arctic. In: Reed, A., ed. Eider ducks in Canada. Report Series No. 47. Ottawa: Canadian Wildlife Service. 55-73.

BOERTMAN, D., MOSBECH, A., FALK, K., and KAMPP, K. 1996. Seabird colonies in western Greenland. Technical Report No. 170. Copenhagen: National Environmental Research Institute. 148 p.

CASWELL, H. 1989. Matrix population models: Construction, analysis, and interpretation. Sunderland, Massachusetts: Sinauer Associates Inc. 328 p.

CHAPDELAINE, G., BOURGET, A., KEMP, W.B., NAKASHIMA, D.J., and MURRAY, D.J. 1986. Population d'eider à duvet près des côtes du Québec septentronial. In: Reed, A., ed. Eider ducks in Canada. Report Series No. 47. Ottawa: Canadian Wildlife Service. 39-50.

CIRCUMPOLAR SEABIRD WORKING GROUP. 1997. Circumpolar eider conservation strategy and action plan. Akureyri, Iceland: Conservation of Arctic Flora and Fauna. 24 p.

COOCH, F.G. 1965. The breeding biology and management of the northern eider (Somateria mollissima) in the Cape Dorset Area,
Northwest Territories. Wildlife Management Bulletin Series No. 2. Canadian Wildlife Service. 68 p.

1986. The numbers of nesting northern eiders on the West Foxe Islands, NWT, in 1956 and 1976. In: Reed, A., ed. Eider ducks in Canada. Report Series No. 47. Ottawa: Canadian Wildlife Service. 114-118.

COULSON, J.C. 1984. The population dynamics of the eider duck Somateria mollissima and evidence of extensive non-breeding by adult ducks. Ibis 126:525-543.

DICKSON, D.L. 1997. Introduction. In: Dickson, D.L., ed. King and common eiders of the western Canadian Arctic. Occasional Paper Series No. 94. Ottawa: Canadian Wildlife Service. 5.

ERIKSTAD, K.E., and TVERAA, T. 1995. Does the cost of incubation set limits to clutch size in common eiders Somateria mollissima? Oecologia 103:270-274.

FABIJAN, M., BROOK, R., KUPTANA, D., and HINES, J.E. 1997. The subsistence harvest of king and common eiders in the Inuvialuit Settlement Region, 1988-1994. In: Dickson, D.L., ed. King and common eiders of the western Canadian Arctic. Occasional Paper Series No. 94. Ottawa: Canadian Wildlife Service. 67-73.

FLEMING, B., and McDONALD, M. 1987. A nest census and the economic potential of the Hudson Bay eider in the south Belcher Islands, N.W.T. A report prepared for the Department of Indian and Northern Affairs - GNWT Region, Project Number 176057. Sanikiluaq, Northwest Territories: Municipality of Sanikiluaq. $114 \mathrm{p}$.

FREEMAN, M.M.R. 1970. Observations on the seasonal behaviour of the Hudson Bay eider (Somateria mollissima sedentaria). Canadian Field-Naturalist 84:145-153.

GOUDIE, R.I., BRAULT, S., CONANT, B., KONDRATYEV, A.V., PETERSEN, M.R., and VERMEER, K. 1994. The status of sea ducks in the North Pacific Rim: Toward their conservation and management. Transactions of the 59th North American Wildlife and Natural Resources Conference 59:27-49.

HARIO, M., and SELIN, K. 1988. Thirty-year trends in an eider population: Timing of breeding, clutch size, and nest site preferences. Finnish Game Research 45:3-10.

KERTELL, K. 1991. Disappearance of the Steller's eider from the Yukon-Kuskokwim delta, Alaska. Arctic 44:177-187.

KORSCHGEN, C.E. 1977. Breeding stress of female eiders in Maine. Journal of Wildlife Management 41:360-373.

MANNING, T.H. 1976. Birds and mammals of the Belcher, Sleeper, Ottawa, and King George Islands, N.W.T. Occasional Paper No. 28. Ottawa: Canadian Wildlife Service. 40 p.

McDONALD, M., and FLEMING, B. 1990. Development of a community-based eider down industry in Sanikiluaq: Resource management and business strategies. A report prepared for the Canada-Northwest Territories economic development agreement Project Number 561 510. Sanikiluaq, Northwest Territories: Municipality of Sanikiluaq. 60 p.

McDONALD, M., ARRAGUTAINAQ, L., and NOVALINGA, Z. 1997. Voices from the Bay: Traditional ecological knowledge of Inuit and Cree in the Hudson Bay bioregion. Ottawa: Canadian Arctic Resources Committee.

MEHLUM, F. 1991a. Egg predation in a breeding colony of the common eider Somateria mollissima in Kongsfjorden, Svalbard. Norsk Polarinstitutt Skrifter 195:37-45. 
1991b. Breeding population size of the common eider Somateria mollissima in Kongsfjorden, Svalbard, 1981-1987. Norsk Polarinstitutt Skrifter 195:21-29.

MEHLUM, F., NIELSEN, L., and GJERTZ, I. 1991. Effect of down harvesting on nesting success in a colony of the common eider Somateria mollissima in Svalbard. Norsk Polarinstitutt Skrifter 195:47-50.

MILNE, H. 1974. Breeding numbers and reproductive rate of eiders at the Sands of Forvie National Reserve, Scotland. Ibis 116: $135-159$.

MUNRO, J., and BÉDARD, J. 1977. Gull predation and crèching behaviour in the common eider. Journal of Animal Ecology 46:799-810.

NAKASHIMA, D.J. 1991. The ecological knowledge of Belcher Island Inuit: A traditional basis for contemporary wildlife comanagement. Ph.D. Thesis, McGill University, Montreal, Quebec.

NAKASHIMA, D.J., and MURRAY, D.J. 1988. The common eider (Somateria mollissima sedentaria) of eastern Hudson Bay: A survey of nest colonies and Inuit ecological knowledge. Ottawa: Environmental Studies Revolving Funds Report No. 102. 198 p.

PALMER, R.S., ed. 1976. Handbook of North American birds. Vol. 3. New Haven and London: Yale University Press. 560 p.

PRACH, R.W., SMITH, A.R., and DZUBIN, A. 1986. Nesting of the common eider near Hell Gate - Cardigan Strait polynya, 1980-1981. In: Reed, A., ed. Eider ducks in Canada. Report Series No. 47. Ottawa: Canadian Wildlife Service. 127-135.

PRESTRUD, P., and MEHLUM, F. 1991. Population size and summer distribution of the common eider Somateria mollissima in Svalbard, 1981-1985. Norsk Polarinstitutt Skrifter 195: 9-20.

REED, A. 1975. Migration, homing, and mortality of breeding female eiders Somateria mollissima dresseri of the St-Lawrence estuary, Québec. Ornis Scandinavica 61:41-47.

- 1986. Eiderdown harvesting and other uses of common eiders in spring and summer. In: Reed, A., ed. Eider ducks in Canada. Report Series No. 47. Ottawa: Canadian Wildlife Service. $156-175$.

REED, A., and ERSKINE, A.J. 1986. Populations of the common eider in eastern North America: Their size and status. In: Reed, A., ed. Eider ducks in Canada. Report Series No. 47. Ottawa: Canadian Wildlife Service. 156-175.

ROBERTSON, G.J. 1995. Annual variation in common eider egg size: Effects of temperature, clutch size, laying date, and laying sequence. Canadian Journal of Zoology 73:1579-1587.
ROSSNES, G. 1991. Eider exploitation by hunters and trappers on Svalbard during the 19 th and early 20 th centuries. Polar Record 27:47-52.

SMITH, M., and RIGBY, B. 1981. Distribution of polynyas in the Canadian Arctic. In: Stirling, I., and Cleator, H. eds. Polynyas in the Canadian Arctic. Occasional Paper No. 45. Ottawa: Canadian Wildlife Service. 7-28.

SNYDER, L.L. 1941. On the Hudson Bay eider. Occasional Papers of the Royal Ontario Museum of Zoology 6:1-7.

SPURR, E.B., and MILNE, H. 1976. Factors affecting the laying date in the common eider. Wildfowl 27:107-109.

STEHN, R.A., DAU, C.P., CONANT, B., and BUTLER, W.I., Jr. 1993. Decline of spectacled eiders nesting in western Alaska. Arctic 46:264-277.

STIRLING, I. 1997. The importance of polynyas, ice edges, and leads to marine mammals and birds. Journal of Marine Systems $10: 9-21$.

STIRLING, I., and CLEATOR, H., ed. 1981. Polynyas in the Canadian Arctic. Occasional Paper 45. Ottawa: Canadian Wildlife Service. 73 p.

SUYDAM, R., QUAKENBUSH, L., JOHNSON, M., GEORGE, J.C., and YOUNG, J. 1997. Migration of king and common eider past Point Barrow, Alaska, in spring 1987, spring 1994, and fall 1994. In: Dickson, D.L., ed. King and common eiders of the western Canadian Arctic. Occasional Paper Series No. 94. Ottawa: Canadian Wildlife Service. 21-29.

SWENNEN, C. 1976. Population structure and food of the eider Somateria $m$. mollissima in the Dutch Wadden Sea. Ardea 64:311-371.

__ 1983. Reproductive output of eiders Somateria $m$. mollissima on the southern border of its breeding range. Ardea $71: 245-254$.

. 1989. Gull predation upon eider Somateria mollissima ducklings: Destruction or elimination of the unfit? Ardea 77:21 44.

1990. Dispersal and migratory movements of eiders Somateria mollissima breeding in the Netherlands. Ornis Scandinavica 21:17-27.

WAKELEY, J.S., and MENDALL, H.L. 1976. Migrational homing and survival of adult female eiders nesting in Maine. Journal of Wildlife Management 40:15-21.

WATSON, M.D., ROBERTSON, G.J., and COOKE, F. 1993. Egglaying time and laying interval in the common eider. Condor 95:869-878.

WEIN, E.E., FREEMAN, M.M.R., and MAKUS, J.C. 1996. Use and preference for traditional foods among the Belcher Island Inuit. Arctic 49:256-264. 